\title{
Stylistic Analysis of the Short Story 'The Last Word' by Dr. A. R. Tabassum
}

\author{
Abdul Bari Khan \\ University of Lahore (Sargodha Campus), Pakistan \\ E-mail: a.barikhan43@yahoo.com \\ Madiha Ahmad (Corresponding author) \\ University of Lahore (Sargodha Campus), Pakistan \\ E-mail: madihaahmad1991@gmail.com \\ Sofia Ahmad \\ University of Lahore (Sargodha Campus), Pakistan \\ E-mail: sofiaahmad0@gmail.com \\ Nida Ijaz \\ University of Lahore (Sargodha Campus), Pakistan \\ E-mail: nida_24capri@yahoo.com
}

Doi:10.7575/aiac.alls.v.6n.3p.10

Received: 03/01/2014

URL: http://dx.doi.org/10.7575/aiac.alls.v.6n.3p.10

Accepted: 01/03/2015

\begin{abstract}
In this article stylistic analysis of short story 'The Last Word' by Dr. A. R. Tabassum is performed. The formative elements of the story, such as point of view, characters and allegorical element, are discussed in detail so as to give a better insight of the story. The story is analyzed stylistically in terms of figures of speech where grammatical, lexical and phonological schemes are considered, following the checklist of linguistic and stylistic categories proposed by Leech and Short. Features of repetition, parallelism, alliteration, consonance, assonance and rhyme are focused on. Finally, the findings and conclusion is given to sum up the discussion.
\end{abstract}

Keywords: stylistics, analysis, short story, last word, allegory, Tabassum

\section{Introduction}

The article aims to explore and investigate that how particular choices made by the writer contribute to create particular meanings. The story selected for the purpose of stylistic analysis is 'The Last Word' by Dr. Abdur Rashid Tabassum, who is the first winner of the Patras Bukhari Award for English Literature instituted by Pakistan Academy of Letters. Munawar S. Khalid (2009, November 02) remembers him as one of the outstanding Pakistani literary authority who has written more than three dozen books in English, Persian and Urdu.

The story under consideration for the purpose of present analysis is from his book of short stories 'A Window to the East', for which he received award along with cash prize from the President of Pakistan in 1983.

\section{Literature Review}

\subsection{What is stylistics?}

Stylistics is a branch of applied linguistics, originated as a way of applying linguistic models to literary text. Widdowson (1975) defines it as "the study of literary discourse from a linguistic orientation". According to Short and Candlin (1989) stylistics is an approach to the analysis of literary texts using linguistic description.

However, the term has been a controversial one as there are a number of approaches and orientations which the analyst may adopt. These varied approaches, as Wales (1989) observes, are "due to the main influences of linguistics and literary criticism". While Widdowson (1975) is of the view that stylistics is a link between the disciplines; literary criticism and linguistics, David Crystal (1980) sees stylistics as a part of linguistics which "studies certain aspects of language variation". In this sense stylistic analysis tends to explore and explain the particular choices made by the writer/author in the selection of words and sentence structure. In other words the style employed by the author serves to present a particular emotion and meaning. Leech and Short (2007) also explain style as the way of the writer to convey message to the reader.

\subsection{Stylistic Analysis}

Traditionally stylistic analysis was seen as a way of exploring the meaning of literary text but now it has gone beyond this structuralistic approach and moved towards a more pragmatic orientation to "link choices in text to social and 
cultural context" (Thornborrow \& Wareing, 1998). According to this view an author makes certain choices in relation to the particular context.

This does not imply that the trend of exploring the meaning in stylistic analysis has changed altogether. Along with the discovery of meaning, stylisticians have started taking interest in the ways in which features of text: particular choice of words are viewed in relation to the context in which it is produced and received.

Though different in their approach, all these research works are aimed towards the same goal i.e. to study and explore the choices made by the writers and how these choices create the effect that writer wishes to communicate to the readers. These choices can create deviations in the text by employing the stylistic feature and characteristics of some other genre.

\section{Methodology}

The study involves the stylistic analysis of a short story The Last Word by Dr. A. R. Tabassum with the aim of looking at the writer's choice of language. The analysis is carried out following the heuristic checklist of linguistic and stylistic categories presented by Leech and Short (2007). The checklist provides a 'systematic basis' for the collection of relevant linguistic data from the text for the purpose of stylistic evaluation and offers four levels for analyzing the linguistic choices made by the writer, in terms of style. These levels include the lexical categories, grammatical categories, figures of speech and context and cohesion. Leech and Short (2007) point out that while the list itself is selective one, leaving out a lot of detail but it allows the reader to reach the significant and relevant features of the text through linguistic survey.

This study will be focused on the level of figures of speech, taking into consideration the grammatical, lexical and phonological schemes. The grammatical and lexical schemes will be searched in form of parallelism, anaphora and lexical repetitions. The phonological patterns of rhyme such as alliteration, consonance, assonance and rhyming words will be discussed under the heading of phonological schemes.

In order to show the literary relevance of the linguistic choices made by the writer, the discussion is winded up discussing the story in terms of metaphor, allegory and personification.

\section{About the story}

\subsection{Point of view}

The story is narrated by first- person narrator, who is also the protagonist of the story. The thoughts, actions and dialogues of other characters are conveyed to us by the narrator's point of view. The narration is in fact in form of a farewell speech. The narrator is speaking in such manner as if he is connecting with his listeners and as if he knows how they think and feel. Following instances from the text serve best to illustrate this point.

"Mates and friends! You are whispering in each other's ears. I know what you mean.

"Let me tell you something however incredible it may sound."

"Mates and friends! Now don't wink at each other ominously."

\subsection{Characters}

All the characters are nameless. There is a gardener who is addressing his fellow gardeners as he is departing from the garden. The fellow gardeners are very much concerned about the journey which the protagonist is going to undertake because "the way is long and full of uncertainty" and the protagonist is disfigured and weak however he advises them not to worry about him and get back to work because "the gardener is hard to please". This certainly indicates the presence of a supervisor.

Then there is the "sweet-heart", who is calling the gardener to accompany her to some unknown destination where he would be rewarded with his wage of love.

Finally there are the beauties of the garden who will live in the 'eternal songs' of the gardener when he is gone.

\subsection{Allegory}

The story is allegorical and metaphorical one as it contains two levels of meaning.

At surface level there is a gardener taking leave from his fellows before leaving the garden. This leave taking is in form of an address, but the language used is clearly not suited to a gardener. The garden is used as a metaphor for the world. So at a deep level it is the farewell speech of a man leaving the world.

The phases of the sun are the metaphor for the different phases of man's life as in:

"Mates and friends! Today at dawn the nightingale sang a sweet and melodious song which, I know, was a message from my sweetheart calling me back. As the sun rose high, the lovely drops of the dew, precariously balanced on the thorns of the rose bush, beckoned me to follow them to her and then they ominously left the bush. Now the sun is on the decline." 


\section{Analysis}

\subsection{Grammatical and lexical schemes}

\subsubsection{Parallelism and anaphora}

The story contains various parallel structures. The story contains parallelism on the phonemic, word and syntactic levels. Anaphora occurs where many successive clause or sentences start with the same word or clause. Following instances of anaphora and parallel syntactic structure are found in the text, which are in big proportion if we consider the total length of the story.

"Here is my shovel, here is my basket, and here is my dusty shirt smeared with sweat and dirt."

"Why have you dropped your scythes from your hands in despair? Why has sweat dried suddenly on your forehead? Why have you turned pale?"

"His body is disfigured with bruises and wounds and his heart is bleeding. His hair is unkempt, his face is not given a wash and his skin is sunburned."

Worry you not if the way is long and full of uncertainty, the night is dark, and I disfigured and weak.”

"I moaned. I screamed."

"She paused. She pondered."

"I could not scan the dust on your face, could not gauge the depth of your wounds, could not hear the beats of your aching heart, and could not feel the bruises you had."

\subsubsection{Repetition}

There is a lot of repetition of certain phrase, clauses and words

Mates and friends!

I must depart from you

My sweetheart has called me back.

Besides the phrase and clauses mentioned above, certain nouns are frequently repeated. These are:

Dust, bruises, wounds, dark, storm, heart, despair, night, sweetheart, beauty, sun, garden, song

Verbs like sigh, sobbed and loved are also repeated time and again. Modal auxiliaries must, will and should are also frequently used.

There are certain other devices which are made use of by the writer in abundance. These are:

i. Rhetoric questions:

Protagonist also makes use of the technique of rhetoric questioning, which is an important feature of speech.

"Why have you dropped your scythes from your hands in despair? Why has sweat dried suddenly on your forehead? Why have you turned pale?"

ii. Apostrophes:

The protagonist has also made a frequent use of apostrophes, such as

Mates and friends!

O rose!

O tulip!

O narcissus!

O beauties of the garden!

\subsection{Phonological schemes}

\subsubsection{Alliteration}

The repetition of initial consonant sounds in closely occurring words is called alliteration. The text under study displays numerous instances of alliteration.

'...... and here is my dusty shirt smeared with sweat and dirt.'

'Why has sweat dried suddenly on your forehead?'

'During the last watches of the last night while lying in my dark room....'

'Then she smiled and said to me:'

'You are exactly what I wanted you to be.'

'....the nightingale sang a sweet and melodious song.

'..........beauty of $\boldsymbol{m y} \boldsymbol{m a n}$.

'......the lovely drops of dew...... 
"And the dark and stormy night is drawing nigh......."

\subsubsection{Assonance}

Assonance is the repetition of similar vowel sounds in closely occurring words. Following instances of assonance are found in the text.

......and here is my dusty shirt smeared with sweat and dirt.

"And the dark and stormy night is drawing nigh.......'

\subsubsection{Consonance}

There is repetition of ' $\mathrm{s}$ ', ' $\mathrm{t}$ ' and ' $\mathrm{d}$ ' sounds in these lines.

..... his skin is sunburned.

'....... and here is my dusty shirt smeared with sweat and dirt.'

'Why has sweat dried suddenly on your forehead?'

\subsubsection{Rhyme}

"Then she smiled and said to me:

You are exactly what I wanted you to be.”

\section{Findings}

The writer has made use of apostrophes and rhetorical questioning to give the story form of a speech. In fact the whole story is an address to the mates and friends and the beauties of the garden. 'Mates and friend' is repeated 5 times.

There is a lot of sound repetitions in the story. The writer has made abundant use of sound devices in a compact way. He has made selection of such words and organized them in such way that different sound devices are incorporated within the stretch of a single sentence. One such instance is

'....... and here is my dusty shirt smeared with sweat and dirt.'

In this sentence there is repetition of the initial consonant sounds ' $d$ ' and ' $s$ ' in dusty and dirt and smeared and sweat. Then there is repetition of 'er' sound in shirt and dirt. There can also be noticed the repetition of ' $t$ ' sound in dusty, shirt, sweat and dirt. Hence in this sentence writer has made use of alliteration, assonance and consonance all at the same time.

\section{Discussion}

The story works at two levels of meaning. At one level there is a gardener who is addressing his fellow gardeners before his departure. At the deeper level the story is a farewell speech in a metaphorical way. The actions of all the other characters in the story are made known to us solely from the speech of the protagonist, as he goes along narrating that what they are doing and what they are saying and what they are thinking. Thus, by using this technique, the writer achieves two ends. Firstly, all the action is conveyed to the reader in a very economical way. Secondly, a strong bond between the protagonist and the other characters in the story is rendered, where all the other gardeners are worried for the protagonist and the protagonist too is well aware of their concerns, without them addressing him directly, and he is consoling them saying that he has to go now but they must keep the garden in order, and take care of the beauties of the garden, as he is a great admirer of them and that they will remain in his eternal songs. The 'eternal songs' might be the reference to the works of the writer himself. In this way it can be said that the writer is referring to himself as the gardener who has always admired and 'loved beauty as a whole', and that even though he would be gone but his songs will remain forever. The sweetheart is the personification of death and the beauties of the garden are the things or values cherished and valued by the writer.

\section{Conclusion}

The use of apostrophes and rhetorical questions have given the story the form of an address, which apparently is delivered by a gardener, on his departure from the garden, to his fellow gardeners. However the language used by him is not suited to a gardener as it is very formal and eloquent and full of musicality. The use of rhyming, alliteration, consonance and assonance is made to create a musical sound pattern. These evidences show that the address is actually the consolatory speech of someone who is about to leave the world and the address is made in an allegorical way. In this way the garden is the metaphor for the world and the different phases of the sun mentioned by the protagonist are the different phases of man's life.

\section{References}

Crystal, D. (1980). A first dictionary of linguistics and phonetics. Boulder, Colo.: Westview Press.

Khalid, M. S., (2009, November 02). Dr. A. R. Tabassum remembered. Dawn.com. Retrieved from http://www.dawn.com/

Leech, G., \& Short, M. (2007). Style in fiction: A linguistic introduction to English fictional prose (2nd ed.). London: Longman. 
Short, M. \& Candlin, C. (1989) Teaching study skills for English literature. In M. Short (Ed.) Reading, Analysing and Teaching Literature. London: Longman.

Tabassum, A. (1981). The Last Word. In A Window to the East: Short Stories. New York: Vantage Press.

Thornborrow, J., \& Wareing, S. (1998). Patterns in Language: Stylistics for Students of Language and Literature. London: Routledge.

Wales, K. (1989). A dictionary of stylistics. London: Longman.

Widdowson. H. G. (1975). Stylistics and the Teaching of Literature. London: Longman.

\section{Appendix}

\section{The Last Word}

Mates and friends! Here is my shovel, here is my basket, and here is my dusty shirt smeared with sweat and dirt. My sweet- heart has called me back. I must depart from you.

Why have you dropped your scythes from your hands in despair? Why has sweat suddenly dried on your forehead? Why have you turned pale? I must go, my sweetheart has called me back.

Many of our mates and friends have departed from time to time but we kept the garden in order. You will do the same when I am gone.

Take up your scythes and get to work. The tulips are to be cleared of weeds, the bushes of the rose need pruning and the bed of narcissus requires watering. You have to finish your work before dusk. The gardener is hard to please.

Mates and friends! You are whispering in each other's ears. I know what you mean. Some of you are pointing your finger toward me and saying in despair, "His body is disfigured with bruises and wounds and his heart is bleeding. His hair is unkempt, his face is not given a wash and his skin is sunburned. He will not find favor with her. She will certainly reject him. He should not go."

And some of you heave a sigh and add, "And the dark and stormy night is drawing nigh and he is not familiar with the long dreadful path. How can he travel alone! Then he is tired and worn by the day's task. We heard his bones clatter and the basket on his shoulders crack under the heavy loads he carried all the day. Certainly he will perish on his way."

Mates and friends! Worry you not if the way is long and full of uncertainty, the night is dark, and I am disfigured and weak. I must go to her as I am. I must depart from you before the dusk.

Let me tell you something however incredible it may sound. During the last watches of the last night while lying in my dark room I could not sleep, for my wounds pained, my heart ached, and despair made me face the agony of death. I moaned. I screamed. And the wind howled tauntingly outside the room and the storm thundered at me. Then someone peeped through the hole of my window for a long while, heaved a sigh, sobbed, and forced her way into the room. Lo and behold it was "she."

Mates and friends! Now don't wink at each other ominously. Believe me. It was "she." She looked at my disfigured self, counted the beats of my fast- throbbing heart, measured the depth of my wounds, scanned the dust that covered my face, and felt with her hand all the bruises I had. She paused. She pondered. Then she smiled and said to me:

"You are exactly what I wanted you to be. I am proud of you. When I peeped through the window you were wrapped in the darkness of night. I could not scan the dust on your face, could not gauge the depth of your wounds, could not hear the beats of your aching heart, and could not feel the bruises you had. I sobbed. I beat my head against the panes of your window, I thought you had failed me. Wounds, bruises, dust on the head and face and aching heart are the beauty of my man. Come to me before the sun of morrow sets. I want to see all this in the daylight. You have finished your work. Come to me and get your wage of love."

Mates and friends! Today at dawn the nightingale sang a sweet and melodious song which, I know, was a message from my sweetheart calling me back. As the sun rose high, the lovely drops of the dew, precariously balanced on the thorns of the rose bush, beckoned me to follow them to her and then they ominously left the bush. Now the sun is on the decline. You hear the thunder of stormy clouds gathering fast. This is her angry call to me. I must depart and be with her before the sun sets.

O rose! You are the queen of the garden. Remember, I have always loved you passionately. O tulip! I have always pressed you to my heart in the mad ecstasy of unbound love. O narcissus! I have always kissed you with my lips and eyes with the love amounting to worship.

O beauties of the garden! I have always loved and worshipped you all. Remember, I was never a wayward and erring youth. I loved beauty as a whole. I sang the songs of you all. You will live in my eternal songs when I am gone. Now come and bid me farewell with a smile. 